\title{
QUESTIONING THE RIGHT TO BE FORGOTTEN
}

\section{MICHAEL DOUGLAS}

Think back to the most horrible moment of your life. It could be a massive mistake: something you are really ashamed about. Maybe something terrible happened to you, and you don't want to think about it ever again. Now imagine that moment recorded, or recounted, and placed online. For some readers, you would not need to imagine. The internet is littered with the worst moments of people's lives.

Once a moment goes online, it can have lasting significance. Copying and sharing is increasingly easy, and the internet has an almost unlimited capacity to search and remember. David Lindsay describes this as the problem of 'digital eternity'. ${ }^{1}$

Digital eternity is a problem because privacy matters. What should we do about it? Should we do anything? This article questions Europe's controversial response in 'the right to be forgotten'.

\section{The Google Spain case ${ }^{2}$}

In the 1990s, Spanish man Mario Costeja González defaulted on a debt. His house was repossessed and advertised for sale in a newspaper. The advertisement did not just flag the sale; it explained why and identified Mr González by name. The piece found its way onto the newspaper's electronic platform. When you Googled Mr González's name, the results included links to the piece.

A decade after the event, Mr González was getting on with his life. He did not want to be associated with his 90 s misfortune any longer. He wanted the article taken down and links removed from search results. So he complained to the Spanish Data Protection Agency ('AEPD') in respect of the newspaper, La Vanguardia, and the search engine (naming Google Spain and the American Google Inc).

The AEPD dismissed the complaint against the newspaper because the publication was legally justified. (Reporting on such things is what newspapers are for.) However, the complaint against Google Spain and Google Inc was upheld. The Googles took the matter to Spain's National High Court. That Court referred a number of difficult questions to the European Court of Justice.

The questions concerned the interpretation and application of European Union law, ${ }^{3}$ and in particular, the meaning of Directive 95/46/EC on the protection of individuals with regard to the processing of personal data and on the free movement of data. ${ }^{4}$

In a significant decision, the Court held that a search engine like Google should be held responsible for the obligations and guarantees provided in Directive 95/46/EC. ${ }^{5}$ This means that search engine providers have an obligation, in certain circumstances, to remove links to personal data that are inadequate, irrelevant, no longer relevant or excessive. ${ }^{6}$ With this the Court affirmed a right to be forgotten.

\section{Balancing competing rights}

It is important to note that the right to be forgotten is not absolute, and neither is the right to privacy. Rather, these rights need to be balanced against competing rights, such as the right to information. ${ }^{7}$ However the Court held that as a general rule, the right to privacy will trump competing interests. The general position could only be displaced:

if it appeared, for particular reasons, such as the role-played by the data subject in public life, that the interference with his fundamental rights is justified by the preponderant interest of the general public in having, on account of its inclusion in the list of results, access to the information in question. ${ }^{8}$

This is a difficult balance. On the one hand, the right to be forgotten serves the right to privacy. It is widely accepted that at least some privacy is a good thing. We are not handing out the passwords to our emails, or our bankcard PINs. We do not want the worst moments of our lives to be available online forever. Like Mr González, we want to move on.

On the other, enforcement of the right deprives the internet-using public of access to information, which is also widely accepted as a good thing. The Court recognised the value of search providers in providing:

a decisive role in the overall dissemination of those data in that it renders [data] accessible to any internet user making a search ... including to internet users who otherwise would not have found the webpage on which those data are published. ${ }^{9}$

In this same spirit, in November 2014, President Obama defended the value of an open internet, describing it as 'essential to the American economy, and increasingly to our very way of life.' 10

Access to information on the open internet is 'essential' because it is the foundation of open discussion, and so plays an important function in democracies. By providing a vehicle for debate, it assists us in gaining knowledge. As Mill put it, an opinion that 'is not fully, frequently, and fearlessly discussed' is a 'dead dogma, not a living truth.'11 
Further, access to information - and particularly to information that is critical of other individuals - makes us better decision-makers. This is one of the great benefits of ubiquitous internet access. Do I want to go to that restaurant? Fifty per cent of the public says it is horrible, so maybe not.

Which is more important: privacy or access to information? With Google Spain, the EU's position is clear. It favours privacy over access.

\section{The effect of the decision}

Since the decision, internet search providers have been required to respect the right and to take requests for removal of search results. There has been a significant number of requests.

Google started taking requests for removal at the end of May 2014. It is maintaining an updating list of its response to the decision in its Transparency Report. ${ }^{12}$ As of 21 May 2015, it has received 258934 requests for removal, which relate to 938972 URLs. Google has acceded to 41.3 percent of requests.

Bing started taking requests for removal in July $2014 .{ }^{13}$ As of the start of December 2014, it had reportedly received 699 requests relating to 2362 URLs, removing 41.5 per cent of them. ${ }^{14}$ Yahoo! is now also processing requests. ${ }^{15}$

These search providers are evaluating the tsunami of requests internally. They need to, because no judiciary in the world has the resources to deal with this volume of work. The European Court of Justice has taken a fundamentally public responsibility the enforcement of human rights - and placed it on the shoulders of massive corporations. This shifted burden is a real concern.

\section{Unwanted responsibility}

The Court delivered the search engine providers a responsibility they did not want: to balance competing fundamental rights on the internet. Google has made its distaste clear. In 2014 it went on a roadshow around Europe, touring its displeasure. It held a series of public events explaining the impact of the decision and Google's response, and providing a vehicle for Google executive chairman Eric Schmidt to complain about his legal problems. ${ }^{16}$ The PR campaign is understandable. People are divided on whether the right to be forgotten is a good idea. Whatever Google does, sections of the public will be very upset.

This touring spectacle reminds us that no matter how much Google looks like a public utility, it is not a public utility. It is a company. Like any company, it is driven by profit. It seeks efficiencies and to minimise costs. Enforcement of the right to be forgotten is a cost for internet search providers like Google. They will try to minimise that cost.

Put yourself in Google's shoes. You need to enforce this human right, or face the wrath of the European Union. It costs money to do so. Requests are pouring in, and you are met with a very difficult case. Whichever way you go, someone will be upset with you. You want to assess this case (and all cases) carefully, but the longer you take, the more expensive the task.

In my view, in those difficult cases, content will be removed: it is the logical way for Google to (1) minimise risk of a confrontation with the EU, and (2) minimise cost. When there is doubt, data will be forgotten, and freedom of expression will be limited.

This is not mere conjecture: the BBC has highlighted a number of questionable decisions by Google to remove links to its articles. A European Commission spokesman described one decision as 'not a good judgement'. ${ }^{17}$ That is easy for them to say. They do not need to process 1000 removal requests per day. Questionable removal decisions are a significant concern, as the process lacks any formal appeal or any real public accountability.

However good the balance struck in Google Spain sounds, reality is something different. By making human rights protection vulnerable to the vicissitudes of the profit motives of multi-national corporations, the process is considerably weakened.

\section{An inadequate solution}

The right to be forgotten is an inadequate solution to the problem of digital eternity. This is because it is essentially a domestic response - albeit one across a united continent - to a truly global issue.

It is important to remember what the right does. When enforced, only the result in a search result is removed. The source content remains. The Google Spain case did not require removal of the piece naming (and shaming) Mr González. Further, the offending result is only removed in Europe.

Picture yourself on a laptop in a London café. You want to find the original piece on Mr González, and you conduct a Google search accordingly. You use the default URL for your location: google.co.uk. In accordance with the outcome in Google Spain, the results you are looking for are removed. You could then simply type in the American google.com, or the Australian google.com.au. You conduct an identical search. The results that were scrubbed from European Google are available. You go straight to the story, which is still online.

This makes no sense. Europe knows that this makes no sense. In November 2014 an EU Working Party issued guidelines on the implementation of the right to be forgotten. ${ }^{18}$ The guidelines included the following:

In order to give full effect to the data subject's rights as defined in the Court's ruling, de-listing decisions must be implemented in such a way that they guarantee the effective and complete protection of data subjects' rights and that EU law cannot be circumvented. In that sense, limiting de-listing to EU domains on the grounds that users tend to access search engines via their national domains cannot be considered a sufficient mean to satisfactorily guarantee the rights of data subjects according to the ruling. In practice, this means that in any case de-listing should also be effective on all relevant domains, including .com. ${ }^{19}$

With this paragraph, the Working Party essentially called for EU law to apply worldwide. That is a big call. It is not going to happen.

\section{Why not?}

For one thing, America won't let it happen. Although Americans are increasingly wary of intrusions into their privacy, we need to remember that they live in the land of the First Amendment. In the wake of the Google Spain case, Harvard Law School's 
Jonathan Zittrain described the decision as 'a form of censorship, one that would most likely be unconstitutional if attempted in the United States'. ${ }^{20}$ The American response will be decisive: Google alone enjoys more than 90 per cent of the market share for web search in many European countries. ${ }^{21}$ The giants of web search are essentially American.

Further, if the Google Spain decision were to be implemented in the manner proposed by the EU Working Party, it would constitute an interference with the sovereignty of all nations that have differing laws. ${ }^{22}$ Directive 95/46/EC is underpinned by a values hierarchy that is not universal: for example, the Americans prioritise freedom of expression through their Constitution. There is a legitimate basis for Google to continue to ignore the EU Working Party's call for extra-territorial application of EU law. ${ }^{23}$

Even within Europe, the decision has faced considerable criticism. Sajid Javid, Britain's former Secretary of State for Culture, Media and Sport, described the right to be forgotten as 'censorship by the back door' created by 'unelected judges'. ${ }^{24}$ This sentiment will create further difficulties for the decision's implementation. The BBC has retaliated by compiling a list of its articles that have disappeared from Google, which it has threatened to publish online.$^{25}$ Other groups are maintaining their own online records of the censorship. ${ }^{26}$ This is the so-called 'Streisand Effect' at its best: attempts to remove embarrassing content from the internet often just draw more attention.

\section{Coming to terms with the internet}

Regulation of the internet is notoriously difficult. China tries its hardest to keep its people in the dark, but the Chinese find a way around the Great Firewall. George Brandis is really cross, but Australians are prolific consumers of pirated digital media. As Lawrence Lessig puts it, 'code is law': the internet's infrastructure makes it a hard environment to control.

Still, in response to the impracticality objections addressed above, a fan of the right to be forgotten might say that 'just because it is hard to enforce, does not mean that we should not try'. This is a fair point. Indeed, a huge mass of links are removed from search engines in response to claims over intellectual property rights, and allegations of defamation.

Conceding the arguments over impracticality, the case for a right to be forgotten boils down to an argument over values. Google Spain favours privacy above access to information, and so tacitly, values privacy over freedom of expression. Those who support this balance ${ }^{27}$ appeal to values of privacy, autonomy and dignity. Some say that forgetting is an important part of the human condition. ${ }^{28}$ Digital eternity means that we can no longer forget. It is unnatural.

Do you know what else is unnatural? Aeroplanes. Video games. Blue energy drinks. Skydiving. Landing a space probe on a comet. Some of the very best things are unnatural. Just because not forgetting is unnatural does not mean that it is a bad thing.

What is the area of Australia? On what date was Gough Whitlam born? What is a good recipe for cheesecake? Not so long ago, if you could rattle off the answers to these sorts of questions in even reasonably quick succession, you would be labelled a genius. Today, you would be an average person with thumbs and a phone.

The internet has literally extended our minds. ${ }^{29}$ Not forgetting makes us better, faster and stronger. It makes us more productive, more knowledgeable, and better at quiz nights. Digital eternity is an incident of human progress.

\section{The cost of progress?}

Sometimes, remembering can be difficult. In November 2014, Phil Hughes died and the country mourned. Part of the reason why it had such a big impact is that it could happen to so many of us. A lot of people enjoy cricket. Any cricketer can cop a ball in the wrong spot, and it is all over. Any bowler might deliver that unlucky bouncer.

In this case, the bowler, Sean Abbott, was simply playing the game as it is played. So appropriately, our hearts went out to him, and the cricket world publicly threw its support behind him. It was not his fault.

In the midst of the community's mourning, commentator lan Healy reportedly called for us to stop identifying Sean Abbott by name, and said that we should simply refer to 'the bowler'. Some agreed, and asked, why should Sean be linked to this tragic accident forever? ${ }^{30}$

This is one of those difficult cases that divides people on the right to be forgotten. We can all agree it was a tragic accident, but we might disagree on how to respond to it. Out of that discussion, we ought to question:

\section{Do we need to forget, in order to forgive?}

Maybe. Privacy allows for reinvention. Forgetting provides for a fresh start. Thus Healy's comment identifies why we might want a right to be forgotten.

On the other hand, Sean Abbott delivered the bouncer, we all knew his name, and we chose to forgive him with our eyes open. We chose to forgive. That shows that although forgiving and forgetting usually go together, they don't have to.

The values of self-determination and autonomy which underpin the right to be forgotten are only valuable because we are actually free to make choices. We have free will. Thus when embarrassing things happen, we can choose to ignore them, and when accidents happen, we can choose to forgive.

Not forgetting comes at a human cost, but it is not insurmountable. There are many ways to accommodate it. A statutory action for serious invasions of privacy would help fill the hole left by the absence of an Australian right to be forgotten. A forced forgetting will come at a cost, too. It will cost us our right to know. But perhaps more importantly, it will cost us the opportunity to improve our values in pace with improvements in our technology.

Choice is going to become more and more important. The internet will continue, technology will keep developing, and it will be even harder to forget. 'Do we need to forget, in order to forgive?' - is the wrong question. Its answer does not matter.

We can't forget, but we need forgiveness: it is human nature. I am confident that nature will find a way.

MICHAEL DOUGLAS is a lecturer at Curtin Law School. This piece is based on a speech delivered at TEDxSouthBank 2014 at the State Library of Queensland. See <http://tedxsouthbank.com.au/>. 
(C) 2015 Michael Douglas

email: <michael.douglas@curtin.edu.au>

REFERENCES

1. David Lindsay, 'The "Right to Be Forgotten" in European Data Protection Law' in Normann Witzleb et al, Emerging Challenges in Privacy Law: Comparative Perspectives (Cambridge, 2014) 290, 293.

2. Google Spain SL, Google Inc v Agencia Española de Protección de Datos (AEPD) and Mario Costeja González (Court of Justice of the European Union, C-131/12, 13 May 2014)

<http://curia.europa.eu/juris/celex.jsf?celex=62012CJ0131\&lang1=en\&type=TXT\&ancre=> ('Google Spain'). For a case note on point, see Mart Susi, 'The Right to be Forgotten' (2014) 88 Australian Law Journal 608.

3. Including articles 7 and 8 of the Charter of Fundamental Rights of the European Union.

4. Directive 95/46 of the European Parliament and of the Council on the protection of individuals with regard to the processing of personal data and on the free movement of such data, OJ 1995 L 281, adopted 24 October 1995 ('Directive 95/46/EC').

5. Google Spain, above n 2, [58].

6. Google Spain, above n 2, [92].

7. See further Eleni Frantziou, 'Further Developments in the Right to be Forgotten: The European Court of Justice's Judgment in Case C-131/12, Google Spain, SL, Google Inc v Argencia Espanola de Proteccionnde Datos (2014) Human Rights Law Review 1 (forthcoming).

8. Google Spain, above n 2, [97], [99].

9. Google Spain, above n 2, [36].

10. The White House, Net Neutrality: President Obama's Plan for a Free and Open Internet (10 November 2014)

$<$ http://www.whitehouse.gov/net-neutrality>.

11. John Stuart Mill, On Liberty (Longman, 1865) 13.

12. Google, European Privacy Requests for Search Removals (29 April 2015) Google Transparency Report

$<$ http://www.google.com/transparencyreport/removals/europeprivacy/?hl=en>.

13. See Bing, Request to Block Bing Search Results in Europe (2015)

$<$ https://www.bing.com/webmaster/tools/eu-privacy-request>.

14. Stuart Dredge, 'Microsoft and Yahoo Respond to European "Right to be Forgotten" Requests', The Guardian (online), 1 December 2014 <http://www.theguardian.com/technology/2014/dec/01/microsoft-yahoo-right-to-be-forgotten>.

15. See Lisa Fleisher, 'In Europe, Microsoft and Yahoo Have Started to Forget', The Wall Street Journal (online), 28 November 2014 <http://blogs.wsj.com/digits/2014/11/28/in-europe-microsoft-and-yahoo-have-started-to-forget/>.

16. See Charles Miller, 'Google's 'Right to be Forgotten' Tour Comes to London', BBC (online), 17 October 2014 <http://www.bbc.co.uk/blogs/blogcollegeofjournalism/posts/Googles-right-to-be-forgotten-tour-comes-to-London>.

17. See Dave Lee, 'Google Removing BBC Link was "Not a Good Judgement”', BBC News (online), 3 July 2014 <http://www.bbc.com/news/technology-28144406>.

18. WP 225, Guidelines on the Implementation of the Court of Justice of the European Union Judgment on 'Google Spain and Inc $v$ Agencia Espanola de Proteccion de Datos (AEPD) and Mario Costeja Gonzales' C-131-12 (Adopted 26 November 2014).

19. Ibid 3 [7].

20. Jonathan Zittrain, 'Don't Force Google to "Forget”', The New York Times (online), 14 May 2014

$<$ http://www.nytimes.com/2014/05/15/opinion/dont-force-google-to-forget.html?_r=0>.

21. 'Should Digital Monopolies be Broken Up?', The Economist (online), 29 November 2014

<http://www.economist.com/news/leaders/21635000-european-moves-against-google-are-about-protecting-companies-not-consum ers-should-digital>.

22. See further Brendan van Alsenoy and Marieke Koekkoek, 'The Extra-territorial Reach of the EU'S "Right to be Forgotten"' (ICRI Research Paper 20, 19 January 2015) <http://papers.ssrn.com/sol3/papers.cfm?abstract_id=2551838>.

23. See Lance Whitney, 'Google advisers: Limit "Right to be Forgotten" to Europe', CNET (online), 7 February 2015

$<$ http://www.cnet.com/au/news/google-advisers-limit-right-to-be-forgotten-to-europe/>.

24. Nicholas Watt and Mark Sweney, 'Sajid Javid: Terrorists and Criminals are Exploiting "Right to be Forgotten"', The Guardian (online), 12 November 2014

<http://www.theguardian.com/technology/2014/nov/11/sajid-javid-terrorists-criminals-right-to-be-forgotten>.

25. See Dave Lee, 'BBC to Publish "Right to be Forgotten” Removals List', BBC News (online), 17 October 2014

$<$ http://www.bbc.com/news/technology-29658085>.

26. See, eg, Hidden From Google (2014) <http://hiddenfromgoogle.afaqtariq.com/>.

27. For example, Julia Powles, 'What did the Media Miss with the 'Right to be Forgotten' Coverage?', The Guardian (online), 21 May 2014 <http://www.theguardian.com/technology/2014/may/21/what-did-the-media-miss-with-the-right-to-be-forgotten-coverage> 28. Viktor Mayer-Schönberger, Delete: The Virtue of Forgetting in a Digital Age (Princeton U Press, 2009); Jean-Francois Blanchette and Deborah G Johnson, 'Data Retention and the Panoptic Society: The Social Benefits of Forgetfulness' (2002) 18(1) The Information Society 33; Shaun Wilson, 'Remixing Memory on Digital Media' in Joanne Garde-Hansen, Andrew Hoskins and Anna Reading (eds), Save As ... Digital Memories (Palgrave Macmillan, 2009) 184, 193.

29. See Andy Clark and David Chalmers, 'The Extended Mind' (1998) 58(1) Analysis 7.

30. See, eg, Todd Balym (@toddbalym), Twitter (27 November 2014) <https://twitter.com/toddbalym/status/537935134989643776> 